\title{
Growth patterns, diet composition and reproduction in the ten pounder, Elops lacerta from Ologe lagoon, Lagos, Nigeria
}

\author{
${ }^{1}$ Lawson, Emmanuel O. and ${ }^{2}$ Aguda, Abigail F. \\ ${ }^{1,2}$ Department of Fisheries, Faculty of Science, Lagos State University, Ojo. P.O. Box 0001, \\ LASU Post Office, Lagos.
}

\begin{abstract}
Ten pounder, Elops lacerta, a member of the family Elopidae is a tropical and subtropical fish species. Growth patterns, food and feeding habits and reproduction of 317 specimens of $E$. lacerta were investigated in Ologe lagoon, Lagos, Nigeria. Diurnal and nocturnal fishing activities were carried out in the lagoon using cast and gill nets. The specimens examined ranged from 90$375 \mathrm{~mm}$ total length (TL) and weighed $4.7-214 \mathrm{~g}$ body weight (BW) respectively. Of the specimens $49.5 \%$ were juveniles, $36.3 \%$ fingerlings and $14.2 \%$ adults. Specimens were classified as unsex, males and females their growth exponential "b" values were allometric and 2.40, 2.27 and 2.27 respectively meaning the fish become lighter for its length as it grows. These values accounted for the robustness of the fish in Ologe. High correlation coefficient was observed in E. lacerta with $r=0.76,0.97$, and 0.88 for unsex, male and female specimens respectively. 158 males and 64 females were caught giving 1 male:0.41female sex ratio. This was significantly different $(P>0.05)$ from the expected 1male:1female. Diet of the fish consisted of shrimps, plant materials and unidentified food mass. Presence of fish and shrimps in stomachs of the fish indicated its piscivorous and predatory tendency while plant materials connoted its herbivorous habit.
\end{abstract}

Keywords: Growth, fish, lagoon, reproduction

\section{INTRODUCTION}

Ten pounder or West African lady fish, Elops lacerta is a member of the Family Elopidae (Val.)(FAO, 1990). The family comprises of one genus and six species especially found in tropical and sub tropical seas. It is an economically important fish species in Nigerian waters. It is widely distributed in estuaries and coastal waters of tropical and sub tropical region of sea. Its juveniles had been reported in marine, brackish and fresh waters off Lagos Coast, Lagos and Lekki Lagoons in Nigeria by Ugwumba (1984).

Distribution of fish in the sea is related to certain physical and chemical parameters of the water (Hadzley, 1997). Juveniles are typically found at moderate salinities of around 23-25 ppt (McBride et al. 2001), but they have also been collected from a much broader range of 0-45 ppt (Govoni and Merriner, 1978).

The length and weight measurements in conjunction with age data can give information on the stock composition, age at maturity, life span, mortality, growth and reproduction (Diaz et. al. 2000). Lengthweight relationships are useful tool for fisheries research because they allow the conversion of growth in length equation assessment model; allow for the estimation of biomass from the length observation; allow an estimate of the condition of the fish and are useful for between regions comparism of life histories of certain species (Moutopoulos and Stegious 2000). The length weight relationship has been widely used in fish biology with purposes like estimating the mean weight of fish based on known length (Bolger and Connolly, 1989). Various techniques have been used to validate age in fishes in tropical water (Bayagbona, 1969; Tobor, 1969; Ikusemiju, 1973; Fagade, 1973; Ezenwa and Kusemiju, 1981). Length-weight relationship is of great importance in fishery assessment (Garcia et. al. 1998; Haimovici and Velasco, 2000).

The food and feeding habit of fishes vary from season to season. Seasonal changes in temperature not only influence food consumption and rate of digestion but also quality and quantity of available food organism. Studies on the food and feeding habit of some fishes were reported by Hynes (1950); Bhuiyan and Islam (1988); Bhuiyan et al (1992, 1994, 1999).

Matt (1944) reported the predatory tendencies of the genus Elops in a man made lakes in Hawaii. Fagade and Olaniyan (1973) working on the food and feeding interrelationships of fishes in the Lagos lagoon grouped Elops lacerta amongst the piscivorous fishes feeding on Elops species, the clupeids Ethmalosa 
fimbriata, Caranx $s p$ and Trichiurus sp. They also feed on prawns, mostly the penaeid prawns that use the lagoon as a nursery ground. Its feeding especially on fish and shrimps was also reported by Diouf(1996).

The reproductive cycles of fishes are closely tied to environmental changes, particularly seasonal change in light and temperature. These two factors are often most important because they can act directly or through sense organs, or glands that produce hormones which in turn produce the appropriate psychological or behavioural responses. Gonadal growth and development of fishes are classified basically in maturity stages as immature; ripening; ripe and spent. Sex ratio, egg diameter and the gonadotropic indices of the ripe fish have been used as an indicator of gonad development. Studies on gonad histology reveals not just mere developmental stages of the Gonads but throw more light on spawning activities and periods in individual fish species. This was borne out of the contention that the reproductive cycle in a fish involves large changes in the weight and appearances of gonads.

\section{MATERIALS AND METHODS}

Description of study sites: Ologe lagoon: Ologe lagoon (Figure 1) in Lagos, Nigeria lies between $3^{\circ} 02^{\prime} \mathrm{N} 6^{\circ} 27^{\prime} \mathrm{E}$ and $3^{\circ} 07^{\prime} \mathrm{N} 6^{\circ} 30^{\prime} \mathrm{E}$. The Ologe lagoon meets several socio-economic needs. It sustains thriving artisanal fisheries and serves as a source of water for domestic and industrial uses, transportation, logging and sand dredging (Anetekhai et al, 2005). More importantly, it drains river Owo, into which partially treated/untreated effluents from the Agbara industrial estate is discharged. It is a brackish water body which opens into the Atlantic Ocean via the Badagry creeks and the Lagos harbor. It is deep in the centre but shallow at edges, it has a wide navigable mouth, which makes it easy for fishing. Ologe lagoon is inhabited by the Awori and Egun tribes. Ologe is bounded in the north by Igbesa and Agbara (in Ogun State), Otto-Awori and ljanikin towns (in Lagos), west by villages such as Esepe, Mushin, Obele and Araromi-Ale, south by Gbanko village and Badagry creek and in the east by Ikotun,
Idoluwo, Ilemba, Igbede and Ojo towns. Fishing is predominant business of the inhabitants of these adjacent villages and towns around the lagoon. The sampling sites used in the study are Obele, Gbanko, Ibiye, Idoluwo, Otto, and Agbara.

Few literatures exist on the research efforts conducted on Ologe lagoon unlike research works that had been conducted on Lagos, Epe and Lekki lagoons. Kumolu-Johnson (2005) reported 20 families and 34 species, $94.53 \%$ fish, $4.87 \%$ shrimps and 0.69 crabs. Elops lacerta of the Family Elopidae ranked $22^{\text {nd }}$ of the species abundance of the 20 families in Ologe lagoon. Despite its importance economically and ecologically, this species has never been investigated in detail in Ologe lagoon. Study of this species in this lagoon especially aspects of its biology will serve as a baseline data for future studies of this and other fish species in Ologe lagoon.

Field work and laboratory procedures: 317 specimens of $E$. lacerta were collected from the sampling sites (Figure 1) from the diurnal and nocturnal fishing activities. Collections were carried out with cast $(22 \mathrm{~m}$ long with mesh area-size of $2 \mathrm{~cm})$ and gill nets (mesh size: $2 \mathrm{~cm}$ ) with assistance of local fishermen on motorized canoes.

In laboratory, the biometric data such as body weight(BW)and total length(TL) measurements; sex and gonad weight $(\mathrm{GW})$ were recorded for each of the specimens. The total length was taken as the distance from the snout with the mouth closed to the tip of the tail fin.

Length frequency distribution: The specimens were grouped into three size groups using their TL measurements. Length frequency polygons were also plotted from the data obtained from TL measurements of the fish. The modes or peaks were used in the determination of age of the species following that of Petersen method. This was checked with integrated methods of Pauly (1980). 
Agric. Biol. J. N. Am., 2010, 1(5): 974-984

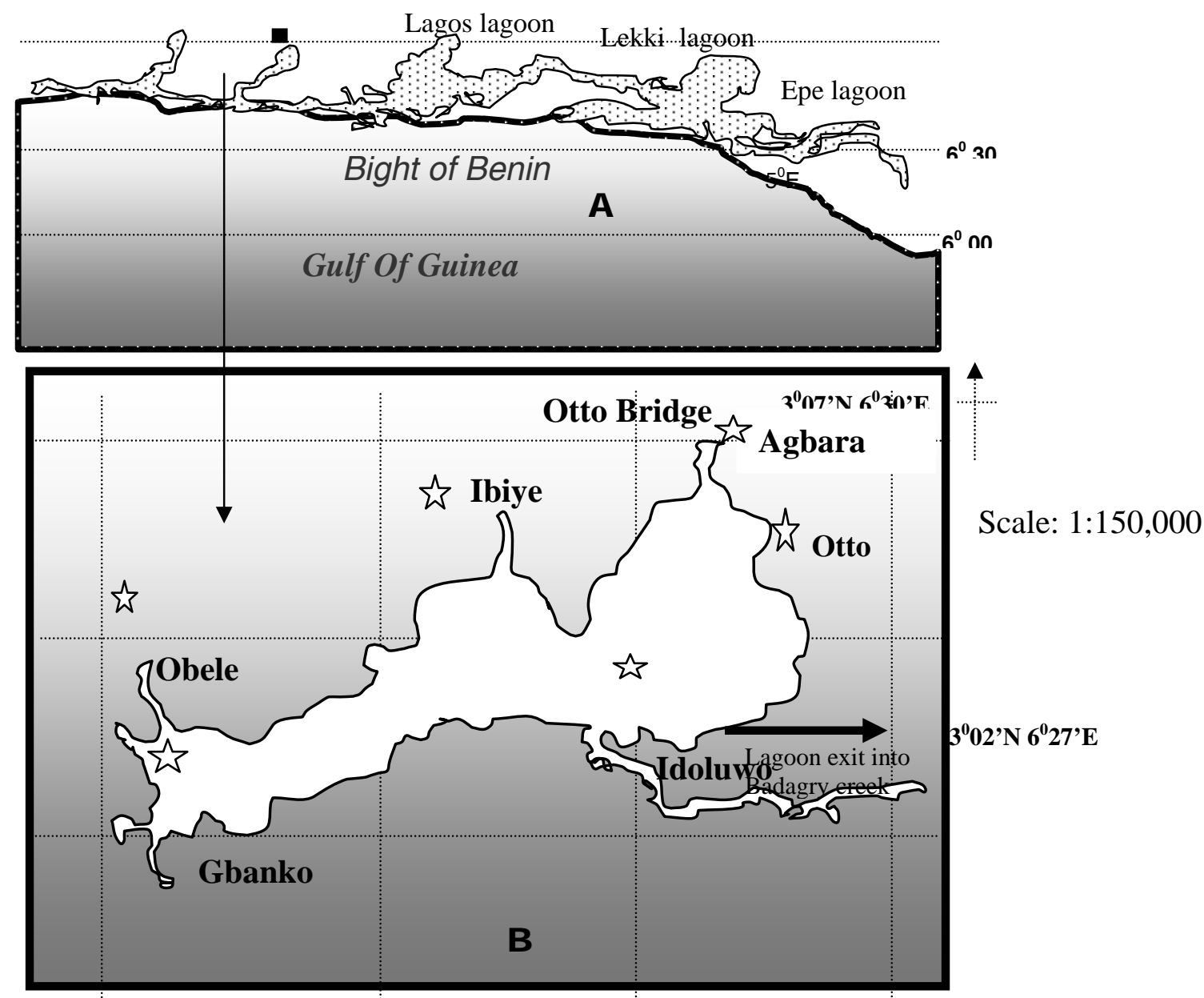

Figure 1: (A) Map of Badagry Creek and Lagoon Complex - inset: Ologe Lagoon (B) Map of Ologe Lagoon showing the sampling sites (marked with stars).

Source: Lagos State University multimedia centre

Length-weight measurement: The body weights were taken on a Harvard triple beam balance to the nearest tenth of a gram. The length-weight relationship of a fish species was represented by the equation:

$$
W=a+b L
$$

The intercept, 'a' was expressed as;

$$
a=\left[\frac{\Sigma Y}{n}-\left(b \frac{\Sigma X]}{n}\right.\right.
$$

The slope, 'b' as:

$$
\begin{aligned}
\mathrm{b}=\Sigma \mathrm{XY}-(\Sigma \mathrm{X})(\Sigma \mathrm{Y}) / \mathbf{n} \\
\Sigma \mathrm{X}^{2}-(\mathrm{b} \Sigma \mathrm{X})^{2} / \mathbf{n}
\end{aligned}
$$

where $L$ or $X=$ total length of fish in millimeters $(\mathrm{mm})$, $\mathrm{W}$ or $\mathrm{Y}=$ body weight of fish in grammes $(\mathrm{g})$ and $\mathrm{n}=$ sample size.

The correlation coefficient, ' $r$ ' as:

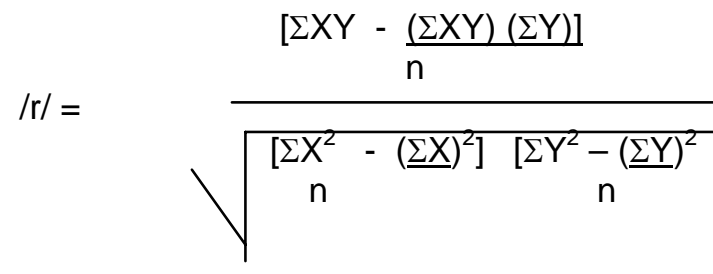

Where $L$ or $X=$ total length of fish in millimeter $(\mathrm{mm})$ 
$\mathrm{W}$ or $\mathrm{Y}=$ body weight of fish in grammes $(\mathrm{g})$ $\mathrm{n}=$ number of fish samples

The relationship was transformed into linear form by the equation.

$$
\log W=\log a+b \log L
$$

Condition factor, " $K$ ": The condition factor $(K)$, which refers to the degree of well being of a fish was recorded. Calculations were made separately for males and females. The condition factor was calculated using the formula.

$\mathrm{K}=\frac{100 \mathrm{~W}}{\mathrm{~L}^{3}}$

Where $\mathrm{K}=$ condition factor, $\mathrm{W}=$ body weight in grams and $L=$ total length in millimeters.

Food and feeding habits: The food analysis was under taken using the numerical and frequency of occurrence methods. These methods followed those of Hyne(1950), Ikusemiju (1975) and Hyslop (1980). The stomachs were removed by splitting from the throat to the anus. The stomach contents were emptied into a Petri dish. The contents were assumed to be the representatives of the last meal of the fish.
Reproductive biology: The Gonadosomatic Index (GSI) of the fish was expressed as a percentage of gonad weight(GW) to body weight (BW) for the freshly collected specimens.

$$
\mathrm{GSI}=\frac{\mathrm{GW}}{\mathrm{BW}} \times 100 \%
$$

The ratio of the number of male to female specimens was determined monthly. Sex ratio was tested by chi square (X2) method. Thus:

$$
X^{2}=\Sigma(O-E)^{2} / E
$$

Where, $\mathrm{O}=$ Observable and $\mathrm{E}=$ Expected

\section{RESULTS}

Length frequency distributions: Size distribution of E. lacerta in Ologe lagoon is presented in Table 1. Specimens were grouped into three size groups. The small or fingerlings (90-169mmTL), medium/juveniles (170-269mmTL) and large/adult(270-375mmTL) representing $36.3,49.5$ and $14.2 \%$ of the population in this study. The age distribution polygons of the species are given in Figure 2. Two(2) modal age progressions were observed in the fish representing $1^{+}$and $2^{+}$age groups respectively. The more dominant was $1^{+}$age group had the mean of

\begin{tabular}{|c|c|c|c|c|c|c|c|}
\hline \multirow[b]{2}{*}{ Month } & \multirow[b]{2}{*}{ Year } & \multicolumn{2}{|c|}{$\begin{array}{l}\text { Small /fingerlings } \\
\text { (90-169mmTL) }\end{array}$} & \multicolumn{2}{|c|}{$\begin{array}{l}\text { Medium/juveniles } \\
\text { (170-269mmTL) }\end{array}$} & \multicolumn{2}{|c|}{$\begin{array}{l}\text { Large ladults } \\
(270-370 \mathrm{mmTL})\end{array}$} \\
\hline & & No & & No & $\%$ & No & \\
\hline October & 2007 & 0 & 0 & 0 & 0 & 0 & 0 \\
\hline November & 2007 & 0 & 0 & 0 & 0 & 0 & 0 \\
\hline December & 2007 & 0 & 0 & 0 & 0 & 0 & 0 \\
\hline January & 2008 & 0 & 0 & 0 & 0 & 0 & 0 \\
\hline February & 2008 & 3 & 2.6 & 47 & 29.9 & 16 & 35.6 \\
\hline March & 2008 & 19 & 16.5 & 13 & 8.3 & 2 & 4.4 \\
\hline April & 2008 & 30 & 26.1 & 35 & 22.3 & 1 & 2.2 \\
\hline May & 2008 & 31 & 27.0 & 13 & 8.3 & 0 & 0 \\
\hline June & 2008 & 16 & 13.9 & 13 & 8.5 & 2 & 4.4 \\
\hline July & 2008 & 16 & 13.9 & 15 & 9.6 & 6 & 13.3 \\
\hline August & 2008 & 0 & 0 & 0 & 0 & 7 & 15.6 \\
\hline September & 2008 & 0 & 0 & 21 & 13.4 & 11 & 24.4 \\
\hline Total & & 115 & 36.3 & 157 & 49.5 & 45 & 14.2 \\
\hline
\end{tabular}
$164.5 \mathrm{~mm} \mathrm{TL}$. The $2^{+}$age group had mean value of 254.5mm TL.

Table 1: Distribution of E. lacerta by size in Ologe Lagoon.

Length weight relationships: In Ologe lagoon Specimens were classified as unsex, males and females. The linear transformation of the length weight relationships of $E$. lacerta are summarized below:

Unsex: $\log W=-4.0+2.4 \log L(n=95, r=0.85)$. 
Figure 3

Males: $\log \mathrm{W}=-4.7+2.75 \log \mathrm{L}(\mathrm{n}=158, r=0.97)$

Figure 4

Females: $\log W=-4.68+2.27 \log L(n=64, r=0.88)$ Figure 5

The growth exponential values $(b=2.40,2.75$ and 2.27) showed the species exhibited negative allometric growth in this study, the fish became lighter for its length as it grows. High correlation coefficient values $(r=0.85,0.97$ and 0.88$)$ were strong indication that the fish body weight increased with corresponding increased in total length.

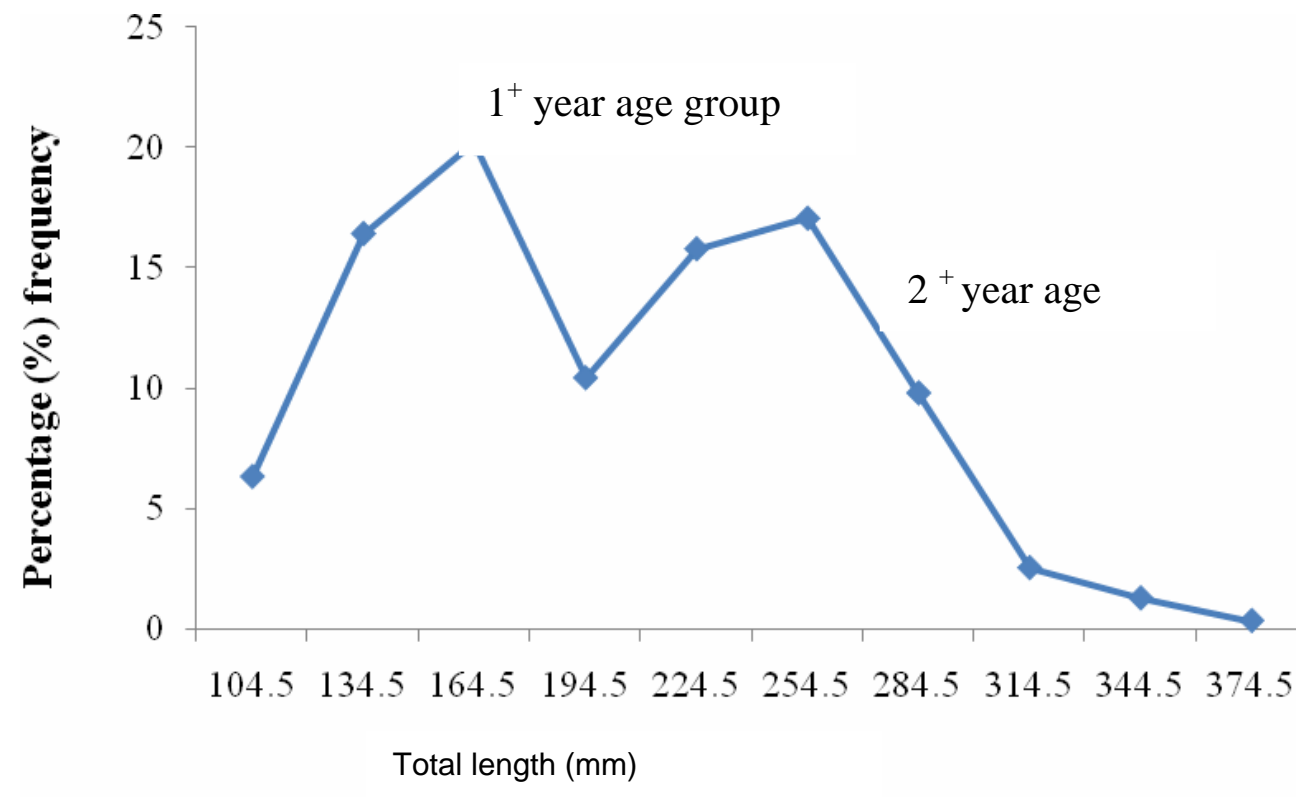

Figure 2: The age distribution polygons of $E$. lacerta 


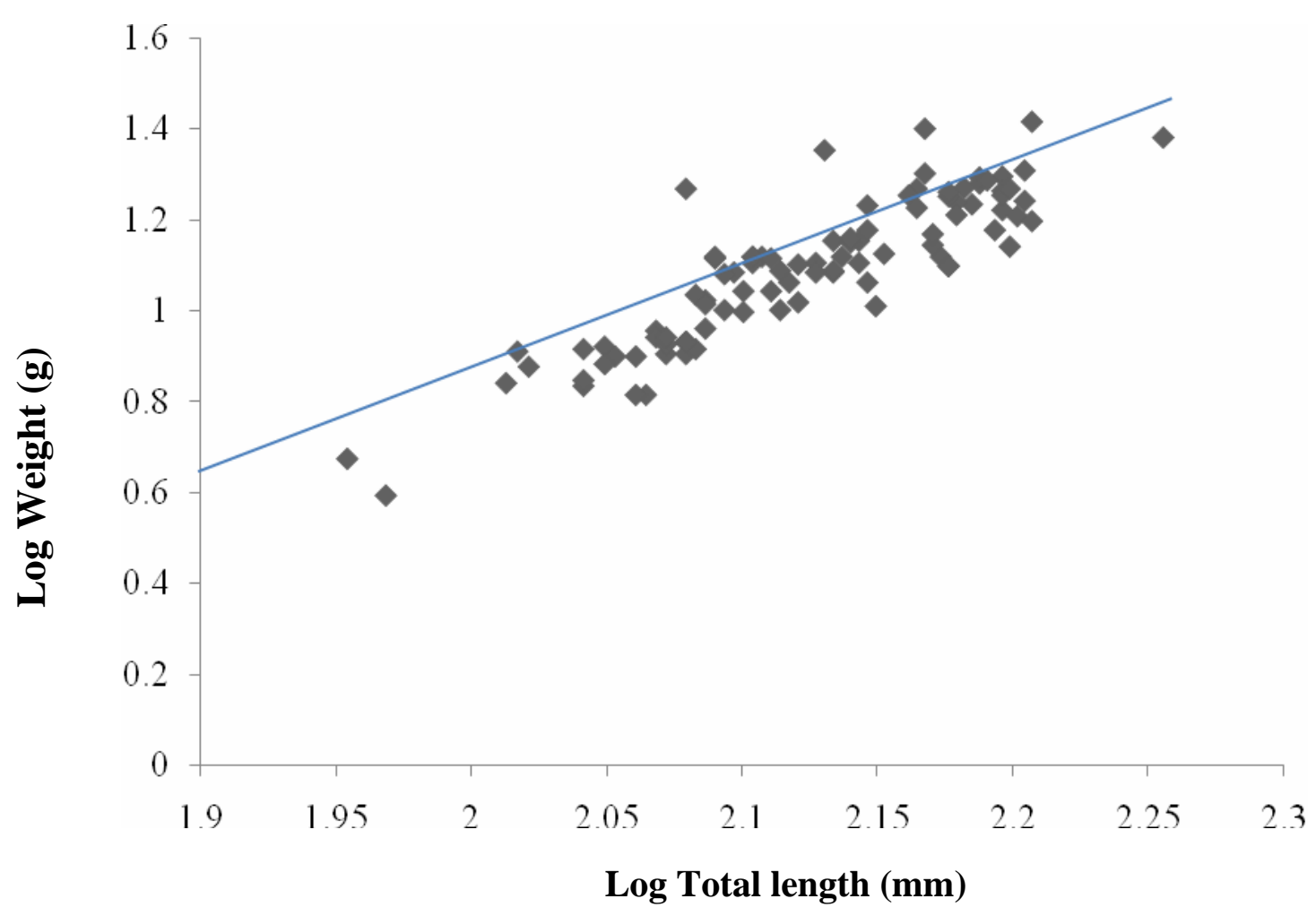

Fig 3: Log Length-weight relationship of unsex specimens of Elops lacerta in Ologe Lagoon, Lagos.

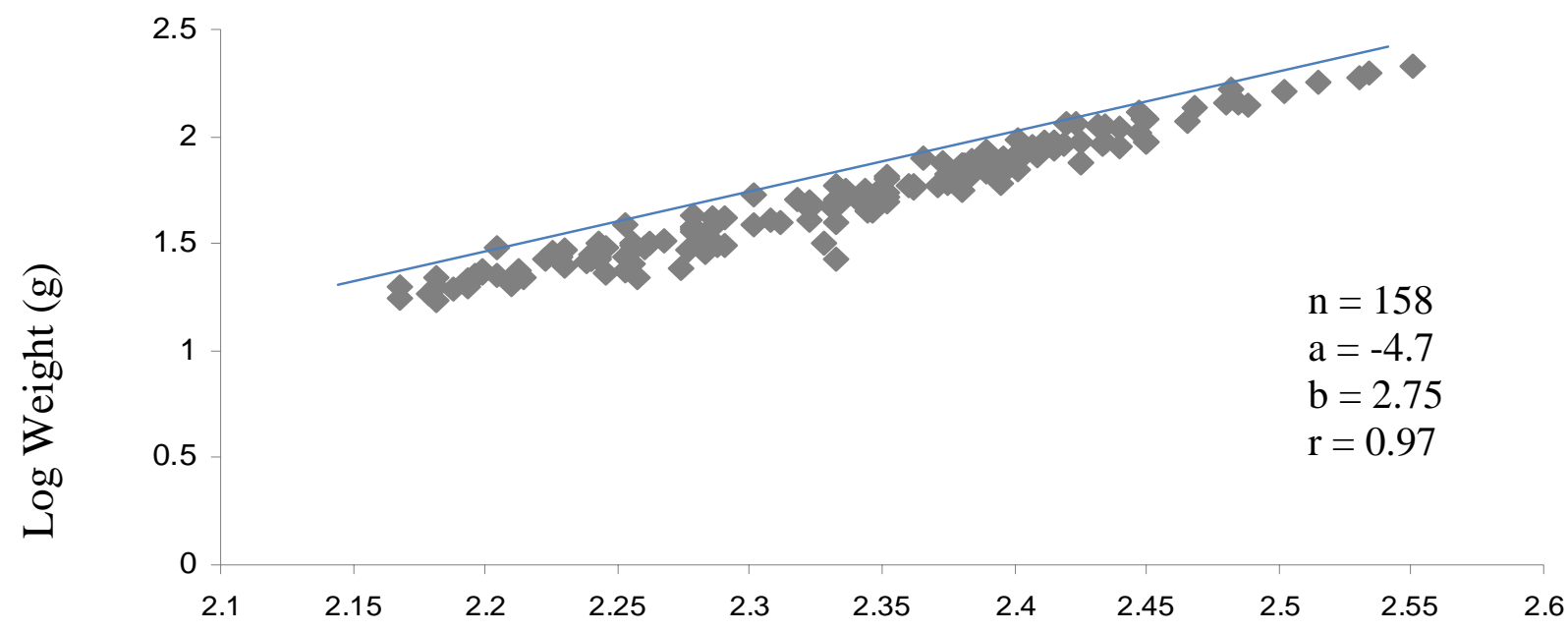

Log Total length $(\mathrm{mm})$

Fig 4: Log Length-weight relationship of male specimens of Elops lacerta in Ologe Lagoon, Lagos 


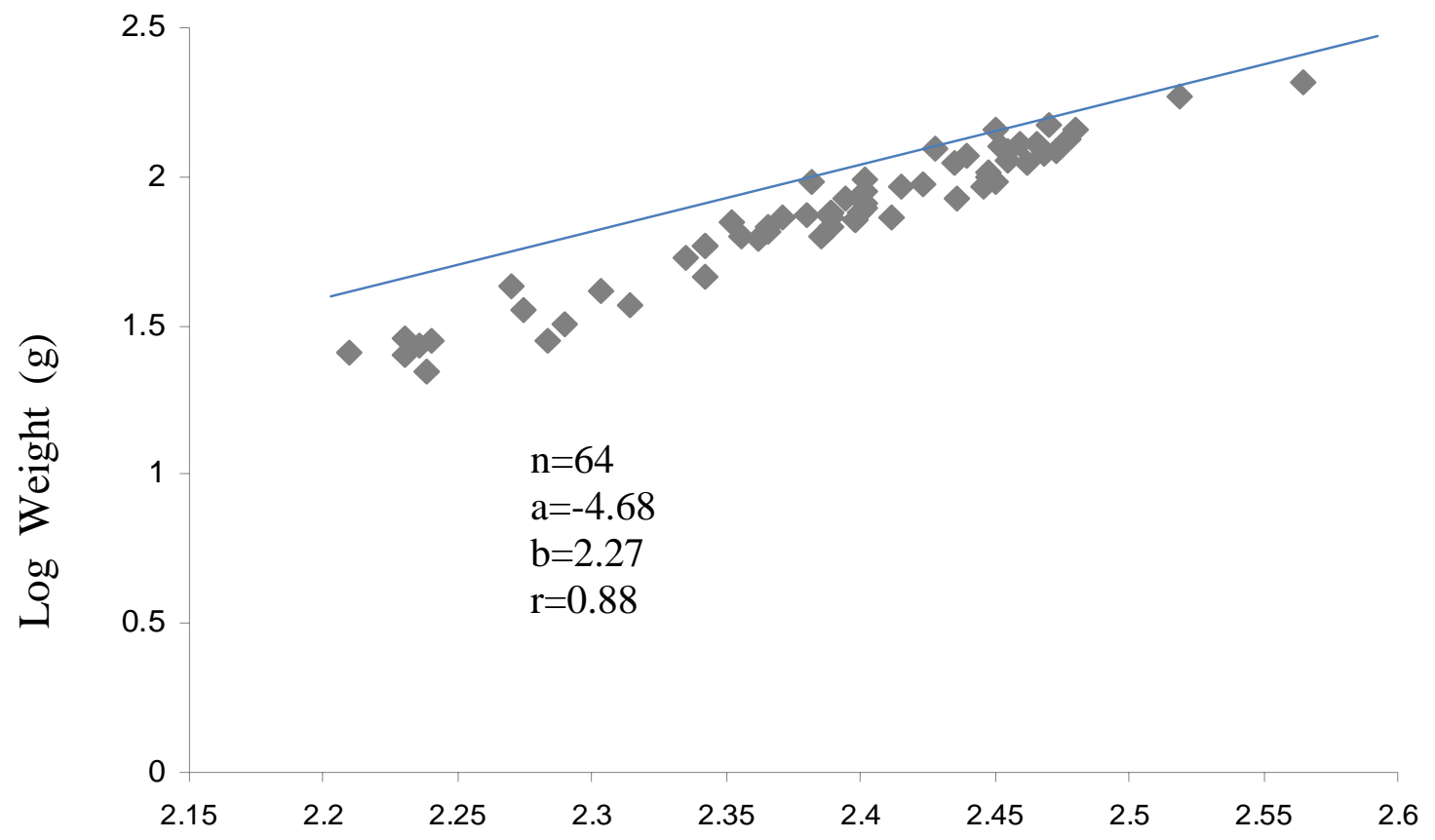

Log Total length $(\mathrm{mm})$

Fig 5: Log Length-weight relationship of female specimens of Elops lacerta in Ologe Lagoon, Lagos.

Table 2: Monthly Condition Factor (K) for males and females E. lacerta

\begin{tabular}{|c|c|c|c|c|}
\hline Month & \multicolumn{2}{|c|}{ Males } & \multicolumn{2}{c|}{ Females } \\
\hline & Sample size & $\begin{array}{c}\text { Range }\left(\mathrm{g} / \mathrm{mm}^{3}\right) \\
\text { (Min - Max) }\end{array}$ & $\begin{array}{c}\text { Sample } \\
\text { Size }\end{array}$ & $\begin{array}{c}\text { Range }\left(\mathrm{g} / \mathrm{mm}^{3}\right) \\
(\text { Min }- \text { Max) }\end{array}$ \\
\hline October, 2007 & 0 & 0 & 0 & 0 \\
November, 2007 & 0 & 0 & 0 & 0 \\
December, 2007 & 0 & 0 & 0 & 0 \\
January, 2008 & 0 & 0 & 0 & $1.01-1.50$ \\
February, 2008 & 35 & $1.00-1.55$ & 26 & $1.30-1.42$ \\
March, 2008 & 12 & $1.04-1.37$ & 3 & $1.02-1.57$ \\
April, 2008 & 30 & $1.02-2.00$ & 10 & $1.00-1.41$ \\
May, 2008 & 18 & $1.00-1.50$ & 4 & $1.07-1.21$ \\
June, 2008 & 12 & $1.00-1.48$ & 6 & $1.03-1.28$ \\
July, 2008 & 22 & $0.91-2.00$ & 2 & $0.90-1.12$ \\
August, 2008 & 5 & $1.02-1.17$ & 7 & $1.03-1.53$ \\
September, 2008 & 25 & $0.8-1.61$ & \\
\hline
\end{tabular}


Table 3: Summary of the food items encountered in the $\mathbf{2 6 2}$ stomachs of $E$. lacerta

\begin{tabular}{|l|ll|lc|}
\hline Food item & \multicolumn{2}{|l|}{ Numerical method } & \multicolumn{2}{l|}{ Frequency of occurrence } \\
& Number & $\%$ & Number & $\%$ \\
\hline Fish & 129 & 49.23 & 161 & 51.44 \\
Shrimp & 69 & 26.40 & 88 & 28.12 \\
Plant materials & 11 & 4.20 & 11 & 3.51 \\
Unidentified food mass & 53 & 20.23 & 53 & 16.93 \\
\hline
\end{tabular}

Table 4: Sex ratio of E. lacerta in Ologe lagoon, Lagos.

\begin{tabular}{|c|c|c|c|c|}
\hline Month & Year & Number of Males & Number of Females & $\begin{array}{c}\text { Sex ratio } \\
\text { Male : Female }\end{array}$ \\
\hline October & 2007 & 0 & 0 & 0 \\
\hline November & “ & 0 & 0 & 0 \\
\hline December & “ & 0 & 0 & 0 \\
\hline January & 2008 & 0 & 0 & 0 \\
\hline February & “ & 34 & 29 & $1: 0.85$ \\
\hline March & “ & 12 & 3 & $1: 0.25$ \\
\hline April & “ & 28 & 11 & $1: 0.39$ \\
\hline May & “ & 18 & 4 & $1: 0.22$ \\
\hline June & “ & 14 & 2 & $1: 0.14$ \\
\hline July & “ & 22 & 6 & $1: 0.27$ \\
\hline August & “ & 5 & 2 & $1: 0.4$ \\
\hline September & “ & 25 & 7 & $1: 0.28$ \\
\hline Total & & 158 & 64 & $1: 0.41$ \\
\hline
\end{tabular}

\section{Condition factor, $\mathrm{K}$.}

In this study the mean condition factor is presented in Figure 6 . The highest mean $\mathrm{K}$ value of $2.0 \mathrm{~g} / \mathrm{mm}^{3}$ was observed in March and lowest value of $1.00 \mathrm{~g} / \mathrm{mm}^{3}$ recorded in August 2008.

Table 2 shows a summary of the monthly condition factor for males and females $E$. lacerta in Ologe lagoon. $\mathrm{K}$ values ranged between 0.8 and $2.0 \mathrm{~g} / \mathrm{mm}^{3}$ for males and from $0.90-1.50 \mathrm{~g} / \mathrm{mm}^{3}$ for females.

\section{Food and feeding habits}

In this study 317 stomachs were examined, 262 stomachs contained food items and 55 were empty representing $82.65 \%$ and $17.35 \%$ respectively. The diet composition of $E$. lacerta in Ologe lagoon is presented in Table 3. The diet is classified into three (3) major groups -Fish, Shrimp and Plant materials. A minor unidentified food mass was also observed in the specimens. Fish foods were mainly fingerlings of thread fins which constituted the $49.23 \%$ by number and $51.44 \%$ by occurrence. Shrimps were the penaeid and second most eaten item numbered $26.40 \%$ and occurring in $28.12 \%$ of the stomachs. Foods of plant origin were the least eaten $(4.20 \%$ by numerical and $3.51 \%$ by occurrence methods).

Sex ratio: The sex ratio of $E$. lacerta is presented in Table 4. Sexes were determined monthly. Of the 317 specimens of $E$. lacerta collected from the Lagoon, 95 were without observable gonads, 158 were males and 64 females giving a sex ratio of 1 male:0.41female. This was significantly different $(P>0.05)$ from the expected 1male:1female meaning the number of males was significantly higher than females in Ologe lagoon. The highest sex ratio of 1 male to $0.85 f$ male was in February and the least ratio of 1 male to 0.14 female in June 2008 . 
Agric. Biol. J. N. Am., 2010, 1(5): 974-984

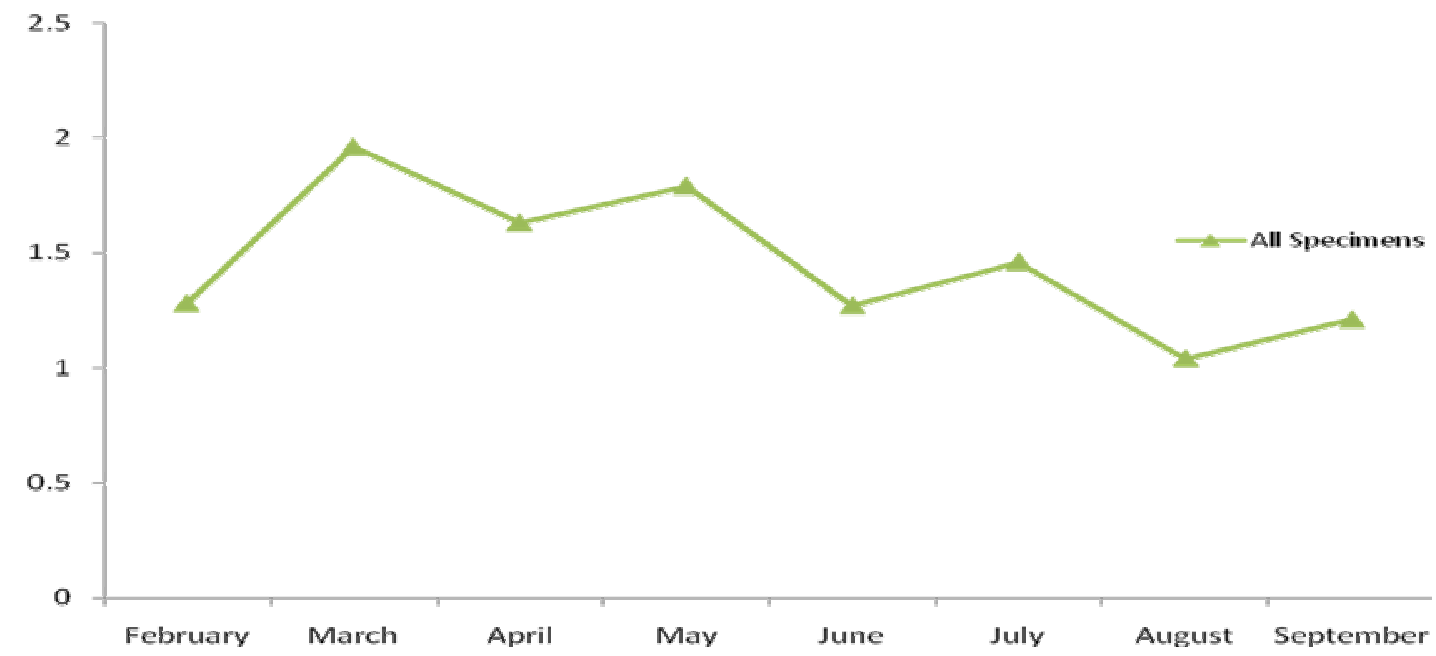

\section{DISCUSSION}

Growth patterns, diet composition and reproduction of $E$. lacerta were examined in Ologe lagoon, Lagos, Nigeria. 317 specimens were caught between October 2007 and September 2008. However, specimens were absent in the lagoon between October 2007 and January 2008. The specimens measured between $90 \mathrm{~mm}$ and $375 \mathrm{mmTL}$ and weighed $4.7-214 \mathrm{~g}$ BW respectively. There are three (3) size groups in Ologe, viz: small/fingerlings, medium/juveniles and large/adults. Juveniles were the most dominant group. Presence of few adults may be related to its migratory nature and suggested that the species probably spawn in the sea. It appears that there was movement of the species to the Ologe lagoon from Lagos coast through the Badagry creek and back to the sea again. Interconnectivity of these water bodies as shown in the Figure 1 might support this. Large number of adult of $E$. lacerta was reported off Lagos coast (marine environment) by Ugwumba (1984). Presence of all stages of life history of a related species, Elops saurus in marine and brackish waters was reported by Nielson (1984). The presence of fewer number of large size groups showed that the $E$. lacerta spawned at sea and that sub-adult fish were mostly recruited into marine environment. This was in agreement with McBride et al, (2001) who reported that West African Ladyfish as offshore spawners.

The growth exponential values, 'b' obtained from the relationship $\mathrm{W}=\mathrm{aL}^{\mathrm{b}}$ (2.40 for unsex, 2.75 for males,
2.27 for females) showed that the growth patterns exhibited in the species were allometric growth which means that the fish became lighter for his length as it grows. This might contributed to its robustness.

The condition factors of the specimens ranged between 0.8 and $2.00 \mathrm{~g} / \mathrm{mm}^{3}$, the low $\mathrm{K}$ indicates that the fish are light for their length which might be due to low feeding intensity and spawning activity (Braga and Germinifilho, 1990). High K value was an assumption of high feeding intensity and gradual increase in accumulated fat that suggested preparation for a new reproductive period. This was in agreement with the work of Braga and Gemenifilho (1988).

The occurrence of empty stomachs is a characteristic feature of predatory fishes which is associated with rapid rate of digesting food. This phenomenon may also be related to regurgitation of large food items from stomachs of predatory fishes by pronounced development of striated muscles of oesophagus extending to the stomachs of $E$. lacerta.

The food items of $E$. lacerta consisted of mainly fish and crustacean (penaeid shrimps). Other food item includes unidentified fish, plant material and juvenile of thread fin fish. The composition of food suggests that Elops lacerta is a predatory species that relies primarily on fish and crustaceans. Fish were the first prey for all individuals. The result agreed with the work of Fagade and Olaniyan (1973) who grouped the $E$. lacerta amongst piscivores feeding on 
juveniles of other fish species and crustaceans mainly the penaeid shrimps. Matt (1944) reported the feeding of Elops species in Hawaiian pond as mainly piscivorous and also included crustaceans, amphipods in its diet. The availability of juvenile pink shrimp that used the lagoon as a "Nursery ground" probably was responsible for the importance of shrimps as food in the lagoon. Plant materials mainly micro algae whose taxonomic status could not be resolved by the study were recorded in the diet of Elop lacerta. Presumably they could have been ingested accidentally while feeding on benthic invertebrates. Eggleston et. al (1998) and Nagelkerken etal (2000) reported that benthic motile invertebrates are relatively dense on sea grass meadow and algal beds.

Monthly sex ratios showed that the male fish were consistently more than the female in Ologe lagoon. Ugwumba (1984) reported a sex ratio in Elops lacerta which was in favour of males in Lekki, Lagos Lagoon and off Lagos coast. It was believed that the spawning activities contributed to the high male to female ratios in favour of the males. Higher percentages of male to female fish in favour of the males during spawning seasons have been noted in Chysichthys walker _(Ikusemiju, 1976) in Scomberomorus maculaths.

\section{REFERENCES}

Bayagbona, E. O. (1969): Age determination and Bertalanffy Growth Pattterns of $P$. typus and $P$. senegalensis using "Burnt Otolith technique". Proceeding of the symposium on the oceanography and fisheries resources of Topical Atlantic, UNESCO. pp 249-359.

Berg, J. (1979): Discussion of the methods of investigating the food of fishes with reference to a preliminary study of the prey of Gobinscuhus flavescens (Gobiidae). Marine Biology, 50: 263-273.

Bhuiyan, A.S; Islam, M.N. and Islam, M.S. (1994): Seasonal pattern of food and feeding habit of Rhinomugil corsula (Ham.) from the river Padma. Uni J. Zool Rajshahi Univ., 13:25-29.

Bhuiyan, A.S; Islam, M.N. and Sultana, N. (1992): Food and feeding habit of Aspdoparia morar (Ham) from the river Padma. Uni J. Zool Rajshahi Univ., 10 and 11:71-76.

Bhuiyan, A.S; Nessa, Q. and Hossain, M.D. (1999): Seasonal pattern of feeding grey mullet Mugil cephalus (L.) . Pakistan J. Zool, 31(3): 295-297.

Bhuiyan, A.S. and Islam, M.N. (1988): Seasonal variation in the percentage composition of the food of
Xenentodon cancila (Ham). Uni J. Zool Rajshahi Univ., 7:33-36.

Bolger, T. and Connoly, P.L. (1989): The selection of suitable indices for the measurement and analysis of fish condition. Journal of Fish Biology 34: 171-182.

Diaz, L.S; Roa, A; Garcia, C.B; Acero, A. and Navas, G. (2000): Lenght-weight relationship of dermersal fishes from the upper continental slope off Colombia. The ICLARM Quarterly 23(3): 23-25.

Diouf, P.S. (1996): Les peuplements de poissons des milieux estuariens de l'Afrique de l'Ouest: L'exemple de l'estuaire hyperhalin du Sine-Saloum. Université de Montpellier II. Thèses et Documents Microfiches 156:267.

Eggleston, D.B; Grover, J.J and Lipcius, R.N (1998): Ontogenetic diet shifts in Nassau Grouper: Trophic Linkages and Predatory impact. Marine Science, 63:111-126.

Ezenwa, B.I.O. and Ikusemiju, K. (1981): Age and growth determination of the catfish, Chysichthys nigodigitatus (L). Journal of Fisheries Biology, 19(3): 345-351.

Fagade, S.O. (1974): Age determination in Tilapia melanotheron (Rupell) in Lagos Lagoon, Nigeria. The aging of fish (T.B. Bagenal) Ed. symposium proceeding, pp 243.

Fagade, S.O. and Olaniyan, C.I.O. (1973): The biology of the West African shad, Ethmalosa fimbriata (Bowdich) in the Lagos Lagoon, Nigeria. Journal of Fisheries Biology, 4: 519-533.

Food and Agriculture Organization (1990): Field Guide to the commercial Marine Research of the Gulf of Guinea.

Garcia, C.B; Buaite, J.O; Sandoval, N; Vonschiller, D and Mello, N. (1998): Length-weight Relationship of Dermersal Fishes from the Gulf of Salaman, Colombia. Fishbyte 21: 30-32.

Govoni, J.J. and Merriner, J.V. (1978): The occurrence of ladyfish, Elops saurus larvae in low salinity water and another record for Chesapeake Bay. Estuaries 1:205206.

Greenwood, P.H; Rosen, D.A; Weitzman, S.H. and Mysers, G.S. (1966): Phylotic studies of teleostean fishes with a provisional classification of living forms. Bull. Amer. Nat. Hist. 131(4):341-455.

Hadzley, H. (1997): Distribution and abundance of the selected fish species (Demersal fish) off the East coast of peninsula Malaysia. Proceeding of Fisheries Research Department of Fisheries, Page 50-71.

Haimovici, M. and Velasco, G. (2000): Length-weight relationship of marine fishes from Southern Brazil. The ICLARM quarterly, 23 (1): 14-16. 
Hynes, H.B.N. (1950): The food of the Freshwater Sticklebacks (Gasterosteus aculeatus and Pyosteus pungitius) with a review of methods used in studies of food of fishes. J. Anim. Ecol., 19: 36-58.

Hyslop, E.J. (1980): Stomach Content analysis - a review of method and their application. Journal of fish Biology, 17:411-429.

Ikusemiju, K. (1973). A study of the catfishes of Lekki Lagoon with particular reference to Chrysichthys walkeri (Bagidae). Ph.D. Thesis, University of Lagos.

Ikusemiju, K. (1975): The bionomics and distribution of the pink shrimp, Penaeus duorarum off Lagos coast, Nigeria. Bull de Inst. Fr. Afr. Noire, 37: 775 - 785.

Kumolu-Johnson, C.A. (2005): Preliminary Report on Fish and Fishes of Ologe Lagoon, Lagos, Nigeria. Third International conference of the Pan -African Fish and Fisheries Association, Cotonou, Benin Republic.

Matt, R.W. (1944): Food chains and the food cycle in Hawaian fish ponds Part: The food and feeding habits of Mullet (Mugil cephalus), Milk fish (Chanos chanos) and the Ten-pounder (Elops machnata). Tans. Amer. Fish. Soc. 74(2):250-261.

McBride, R.S; MacDonald, T.C; Matheson, R.E.; Rydene, D.A and Hood, P.B. (2001): Nursery habitats for ladyfish, Elops saurus, along salinity gradients in two Florida estuaries. Fishery Bulletin, 99:443-458.

Moutopolous, A.K and Stergious, K.I (2000): Length-weight relationship for 40 species of the Aegean sea (Hellas). Journal of Applied Ichthyology, 29 (2): 204.

Nagelkerken, L; Dorenbosch, M; Verberk, I.N; Cocheret , D.E.P; Dela-Moriniere, E. and Vander, G (2000): Day-night shift of fishes between shallow water biotopes of a Caribbean bay with emphasis on the nocturnal feeding of Haemulidae and Lutjanidae. Mar. Ecol. Prog. Ser, 194:55-64.

Nelson, J.S. (1984): Fishes of the World. John Wiley and Sons, NY. 523p.

Pauly, D. (1980): A selection of simple method of assessment of tropical stock. FAO. Fish Circ., 729:15-44.

Pawson, M.G (1990): Using Otolith weight to age fish. Journals of fish Biology, 36: 521-531.

Tobor, J.G. (1965): Identification notes on fishes of the Nigerian trawling grounds. Fed. Fish Occ., Paper 2.

Ugwumba, O.A. (1984): The Biology of Ten- pounder Elops lacerta (Val) in fresh water, estuarine and marine environments. Ph.D. Thesis, University of Lagos. 